\title{
РАЗВИТИЕ РОССИЙСКОЙ НАУКИ ФИНАНСОВОГО ПРАВА: ТРАДИЦИИ И ТЕНДЕНЦИИ
}

Аннотация. В статье рассматриваются этапы генезиса и развития отечественной науки финансового права в лице ее самых ярких представителей: ученых-фринансистов и государственных деятелей. Отмечается, с одной стороны, преемственность, а с другой - утрата связей научных поколений, особенно в период 1917-1940 гг. Анализируются этапы развития отечественной школы финансового права, делается вывод о ее единстве в многообразии региональных школ финансового права, появившихся еще в первой половине ХІХ в. на базе императорских университетов. Подчеркнуты особенности научных исследований санкт-петербургской, московской, казанской, ярославской, киевской, томской, харьковской, одесской, варшавской и юрьевской школ финансового права. Отмечается, что по уровню проводимых финансово-правовых исследований в досоветский период российская научная школа не уступала европейской. Дана оценка вклада советских ученых в развитие теории финансового права. Несмотря на "жесткие» идеологические рамки, изоляцию от мировой науки, советскими учеными были заложены теоретические основы для дальнейшего развития науки финансового права. Именно с советским периодом связывается ее окончательное обособление и самостоятельное место в системе юридических наук. Обоснованы основные направления развития современной российской школы финансового права.

Ключевые слова: наука финансового права, российская школа, тенденции, история, бюджетное право, валютное право, налоговое право, преемственность исследований, денежное обращение, наука о финансах.

DOI: 10.7256/1729-5920.2014.1.9693

$\mathrm{P}$ оссийская наука финансового права: от истоков до фрормирования российской школы финансового права. Отечественная наука фринансового права прошла почти двухсотлетний путь развития, а ее современное состояние во многом является результатом этого процесса ${ }^{1}$. При

1 Лушникова М.В., Лушников А.М. Развитие науки финансового права в России. СПб., 2013. этом надо иметь в виду, что разрабатываемые учеными проблемы, особенно общей части, уже многие десятилетия (даже столетия) не теряют своей актуальности. Обращение к научным наработкам прошлого может придать импульс современным исследованиям, по-иному посмотреть на решения актуальных теоретических проблем современности, естественно с учетом необходимых корректировок.

\footnotetext{
(C) Лушникова Марина Владимировна

* Доктор юридических наук, профессор кафедры трудового и финансового права Ярославского государственного университета им. П.Г. Демидова [mvlushnikova@mail.ru] 150000, Ярославль, ул. Советская, д. 14.
} 
Начнем с того, что юридическая наука начала формироваться в России достаточно поздно относительно стран Западной Европы, а активная фаза этого процесса пришлась на середину XVIII - начало XIX вв., параллельно с развитием системы высшего юридического образования. Еще позже началось выделение самостоятельной науки финансового права. В этой связи изучение российского финансового права через формирование и становление его научных школ позволяет воссоздать относительно полную картину развития данной науки в целом. Первоначально данная наука развивалась в рамках камеральных наук, политической экономии, а затем выделившейся из нее финансовой науки. Только с последней из них наука финансового права размежевалась во второй половине XIX в., причем это размежевание первоначально было неполным и достаточно непоследовательным. Такая «многослойность» делает необходимым поиск истоков финансово-правовой мысли также в политэкономических исследованиях, а затем и в работах по финансовой науке, полицейскому и государственному праву. Подчеркнем, что в досоветский период деление ученых на юристов и экономистов по научной специализации было до известной степени условным.

Вместе с тем в рассматриваемый период мы можем вести речь о формировании российской школы финансового права, которая включала в себя относительно обособленные со своими научными традициями школы финансового права, сформировавшиеся в научных университетских анклавах. В последнем случае такую школу, на наш взгляд, образуют три компонента:

1) личностный - учителя, ученики, администрация, технический персонал учебного заведения, научно-исследовательских учреждений и др.;

2) материальный - материальная база учебного процесса: библиотеки, аудиторный фонд и др.;

3) социокультурный - социальная и культурная среда в городе или населенном пункте, где располагается учебное заведение или научное учреждение.

При некоторой условности понятия в такой трактовке «школа фринансового права», на наш взгляд, имеет полное право на существование ${ }^{2}$.

Лушникова М.В., Лушников А.М. Российская школа финансового права: портреты на фоне времени. Ярославль, 2013.
Некоторые школы (московская, казанская, киевская) были выражены наиболее рельефно, другие (петербургская, харьковская, ярославская, одесская) просматривались достаточно четко. Отдельные школы (дерптская (юрьевская), варшавская, томская) только намечались, однако все они представляли относительно обособленные феномены. Еще раз подчеркнем принципиальное положение. При несомненной важности научного «районирования» все ученые-специалисты в сфере финансового права России принадлежали и принадлежат к единой школе. Она имеет, в свою очередь, «общую родословную», общие корни. Но как в любой семье каждый ребенок, в нашем случае - региональные школы финансового права, имеют свой индивидуальный характер, свою судьбу. При этом каждая школа российского фринансового права - будь-то московская, казанская, дерпская и т.д. - это «птенцы одного гнезда». Помимо очевидной научно-педагогической, языковой, ментальной, нормативно-правовой основы (как базы исследований) близости представителей российской школы финансового права, их объединяет общность исторической судьбы и тесное персональное пересечение. Так, И.Я. Горлов (1814-1890) одним из первых начал читать курс фринансового права и написал первое фундаментальное исследование по теории финансов. Он был выпускником юридического факультета Московского университета, получил ученую степень в Дерптском университете, работал экстраординарным профрессором Казанского университета и только затем перевелся в Петербургский университет, где стал ординарным профессором, а затем и деканом юридического факультета. Бывшие профессора Демидовского юридического лицея, покинув стены вуза, продолжили преподавательскую деятельность: А.А. Исаев (1851-1919,1924?) в Петербургском университете, Э.Н. Берендтс (1860-1924?) - в Императорском училище правоведения (Петербург).

Единство российской школы финансового права обеспечивалось и ее общим «немецким акцентом», когда влияние немецкой школы изначально было преобладающим, а затем неизменно существенным. Не случайно германский ученый В. Рошер выделял «немецко-русскую» школу политэкономии, из которой еще полностью не выделилось финансовое право. К представителям этой школы относились, в частности (А.К.) Шторх, Х.А. Шлецер - первые преподаватели политэкономии и финансовой науки. При этом немецкое влияние было не только опосредованным, но и вполне прямым. 
К тому же в науке финансового права никогда не было острого противостояния региональных школ, хотя некоторые их особенности прослеживаются. Отметим, что научное «районирование» в финансовом праве, как, впрочем, и в других отраслях, никогда напрямую не было связано с административно-территориальным и национальным делением. Оно обосновывалось именно тремя вышеназванными фракторами, которые и определяют понятие «школа». Не отрицая особенностей развития науки финансового права в различных регионах Российской империи и СССР, мы не склонны специально выделять, например, украинскую или польскую школы в соответствии только с национальным признаком, хотя выделение, например, киевской и харьковской школ не вызывает сомнений. В этом плане финансисты Украины кооперировались преимущественно с учеными центральной России, причем это сотрудничество было взаимовыгодным. Так, выпускник Киевского университета (Университета Св. Владимира) И.Т. Тарасов (1849-1929) многие годы преподавал в Демидовском юридическом лицее, а затем в Московском университете. В советский период тот же путь из Киева в Москву проделал В.И. Лисовский (1904-1997). Одновременно шел и обратный процесс. Например, корифей Одесской (новороссийской) школы С.И. Иловайский (1861-1907) был выпускником Петербургского университета. В литературе отмечались следующие общие моменты в биографии харьковских профессоров начала $\mathrm{XX}$ в.: «...почти каждый из них служил в разные годы в университетах разных городов, петербуржцы едут в Харьков, харьковские специалисты отправляются на несколько лет служить в Дерпт (Тарту), Киев, Москву, Петербург, Ярославль и пр. Многие харьковские профессора защитили магистерские и докторские диссертации в Московском университете, многие были связаны работой и учебой с известным Демидовским юридическим лицеем в Ярославле. Такой обмен был не редкостью, ибо условия крупных городов, бытовые и материальные в том числе, не слишком разнились, а в итоге обмен информацией научных школ был значительный» ${ }^{3}$.

Так, каждая школа имела свои специфические черты, число которых, как и яркость выражения, были различными. Так, для московской школы был характерен более

Федорова Е. Безымянное поколение. Гюнтер А. Записки правоведа, адвоката, бывшего меньшевика (18901984). М., 2004. С. 43-44. широкий подход к изучаемым проблемам, интерес к общественной и экономической стороне финансово-правовой проблематики (Ф.Б. Мильгаузен, И.И. Янжул и др.). Не случайно именно в рамках этой школы оформилось социологическое направление финансового права, лидером которого был И.Х. Озеров. Петербургская школа отличалась более строгим, собственно нормативно-догматическим подходом к финансовым проблемам, большим вниманием к проблемам статистики (В.А. Лебедев, Л.В. Ходский, И.И. Кауфмман и др.). Однако это не значит, что представители московской школы уделяли мало внимания проблемам законодательства, а представители петербургской недооценивали важность социологического подхода. Речь идет именно о выделении ведущей черты, характеристики, особенности стиля. Томской школе был свойственен некоторый научный «сепаратизм», подчеркнутое внимание к проблемам местных финансов и приграничной торговли в сибирском регионе (П.С. Климентов, М.Н. Соболев и др.). Казанскую школу отличал повышенный интерес к проблемам истории финансового права и к вопросам таможенно-правового регулирования, таможенных платежей (И.Я. Горлов, Е.Г. Осокин, Д.М. Львов и др.). Киевская школа финансового права отличалась большим своеобразием и даже уникальностью. Достаточно упомянуть то, что ее фактическим основателем и лидером на протяжении почти 30 лет был Н.X. Бунге, который занимал также высшие государственные должности (министр финансов, член Госсовета, председатель Комитета министров), где его финансовые и административно-правовые воззрения отчасти нашли практическое воплощение. Харьковская школа финансового права - скорее школа финансистов-практиков, ее представители тяготели к критическому анализу действующего фринансового законодательства, разработке финансово-правовых реформ, в том числе и на поприще парламентской деятельности (М.М. Алексеенко, П.П. Мигулин и др.). Совершенно очевиден был особый путь развития дерптской школы финансового права. Дерптский университет своим учебным процессом, нравами, языком преподавания (немецкий язык), научно-преподавательским составом был гораздо ближе к германским университетам, чем российским. Действительно, все университеты России, особенно в начале их истории, привлекали к преподаванию иностранных ученых, но ни в одном из них это привлечение преподавателей из-за границы не проводилось столь долго и широко, как 
это практиковалось в Дерптском университете. В разное время кафедры там занимали такие известные ученые, как А. Вагнер, Г. Кнапп, Г. Дитцель.

Советскаянаука финансового права. Отечественная школа финансового права, как впрочем, вся финансовая и юридическая наука, а также соответствующее образование в советский период переживали периодические кризисы.

После Октябрьской революции 1917 г., в период военного коммунизма наука финансового права оказалась в числе невостребованных государством. Лишь в период нэпа интерес к финансовым знаниям возродился, но ненадолго. В этот период исследования в сфере финансов продолжила «старая гвардия», получившая образование в дореволюционной России или за рубежом (Л.Н. Юровский, М.И. Боголепов и др.). Кроме того, по инициативе наркома финансов Г.Я. Сокольникова (1888-1939) в 1921 г. создается Финансовоэкономическое бюро Народного комиссариата фринансов (Наркомфина, НКФ) РСФСР. В рамках Финансово-экономического бюро НКФ функционировали Конъюнктурный институт и Институт экономических исследований (ИЭИ), созданный в 1919 г. (научный руководитель К.Ф. Шмелев, куратор от НКФ - Ю.О. Шмидт, будущий известный полярник). В московском отделении ИЭИ была финансовая секция (председатель П.П. Гензель), секции по денежному обращению (В.Я. Железнов), промышленности и товарообмену (Н.Н. Кутлер) и др. Институт стал органом разработки финансово-экономических вопросов, в котором подвергались предварительному обсуждению основные проблемы фринансового хозяйства страны, а также законопроекты по этой части. С Институтом экономических исследований сотрудничали такие авторитетные специалисты русской финансовой школы, как М.И. Боголепов, А.И. Буковецкий, П.П. Гензель, В.Я. Железнов, К.Я. Загорский, М.Д. Загряцков, С.А. Котляревский, И.М. Кулишер, Н.Н. Любимов, И.Х. Озеров, М.А. Сиринов, М.Н. Соболев, А.А. Соколов, А.Ю. ФиннЕнотаевский, Л.Н. Яснопольский и др. С уходом Г.Я. Сокольникова в 1926 г. с поста наркома финансов СССР окончилась и история Института, закрытого в 1927 г.

Значительная часть видных ученых-финансистов в 30-е гг. XX в. была репрессирована (расстреляна или долгое время находилась в заключении): Г.Я. Сокольников, Л.Н. Юровский, А.Ю. Финн-Енотаевский, С.А. Котляревский, И.Х. Озеров, А.И. Буко- вецкий, Э.Э. Понтович и др. Часть ученых просто «выпала» из научной и общественной жизни или пропала без следа, как, например, Г.И. Тиктин и А.А. Соколов. Разбалансированное в ходе экономической штурмовщины первых пятилеток фринансовое хозяйство представляло собой сомнительный объект изучения в контексте финансового права.

С 30-х гг. прошлого века отечественная наука финансового права утратила свое значение, была замещена марксистско-ленинской политэкономией в ее догматическом варианте. "Железный занавес» закрыл доступ к новым экономическим учениям, которые проходили проверку на практике в западных странах. Финансовое право во многом утратило самостоятельность, «растворялось» то в государственном, то в административном праве. Именно в 30-40-е гг. XX в. была в значительной мере утрачена преемственность научных поколений. Исследования в сфере финансового права объективно ограничивались идеологическими постулатами марксизма-ленинизма. Замалчивались исследования дореволюционных ученых-финансистов, прервалась связь научных школ финансового права.

С 1931 по 1939 гг. фринансового права официально просто не существовало ни в качестве учебной дисциплины, ни в качестве науки, а до середины 50-х гг. велась своеобразная «борьба за выживание». Впоследствии оно преподавалось на кафедрах советского строительства, административного и финансового права (с конца 40-х гг.), а затем - административного и финансового права (с середины 70-х гг.). Финансово-правовая специализация до 90-х гг. не выделялась из административного права, а в рамках экономических наук с 1939 г. защищались диссертации по финансам, денежному обращению и кредиту4. Даже в первых из них наличествует финансово-правовая составляющая. Так, А.И. Буковецкий и Н.Н. Ровинский защитили докторские диссертации в 1940 г. соответственно на темы «Финансовые взаимоотношения Турции и России» и «Государственный бюджет СССР». В изучение проблем финансовых учреждений свою лепту внесли и цивилисты. Так, в 1944 г. Р.О. Халфина (1909-1998) защитила кандидатскую диссертацию «Правовое положение государственного банка СССР». При этом от-

\footnotetext{
4 Диссертации по финансам, денежному обращению, кредиту, бухгалтерскому учету и анализу хозяйственной деятельности, защищенные на ученую степень доктора и кандидата экономических наук с 1939 по 1961 гг. Библиографический указатель. М., 1962.
} 
носительно сбалансированная программа по советскому финансовому праву была утверждена только в 1940 г. Однако даже в ней говорилось о «государственно-правовом характере советских фринансовых правоотношений» (п. 2). Это положение подверг критике известный отечественный цивилист В.К. Райхер последовательный сторонник самостоятельности отрасли и науки финансового права. Он констатировал в 1940 г.: «Наука советского финансового права является одной из самых юных наук в системе высшего юридического образования... Еще не издано ни учебника по фринансовому праву, ни хотя бы учебного пособия, охватывающего сколько-нибудь широкий круг финансовых институтов». Примечательно, что первый учебник по советскому финансовому праву был опубликован в том же 1940 г., а одним из его соавторов был В.К. Райхер. До середины 50-х гг. велась своеобразная «борьба за выживание» этой науки и научной дисциплины. При этом в литературе обоснованно утверждалось, что финансового права как самостоятельной отрасли определенный период времени не существовало ${ }^{5}$.

Некоторое оживление интереса к проблематике фринансового права в 50-х гг. XX в. очевидно. Однако оно не привело к началу «золотых годов» фринансового права, даже в его советском варианте, как об этом иногда указывается в литературе ${ }^{6}$. Более того, некоторые теоретики права, в том числе С.С. Алексеев, О.С. Иоффе и М.Д. Шаргородский, до начала 60-х гг. отказывали в существовании финансовому праву как самостоятельной отрасли права. Но тем не менее с конца 30-х гг. XX в. в значительной степени стараниями представителей московской школы начался этап возрождения науки финансового права. В трудах советских ученых (М.А. Гурвич, Е.А. Ровинский и др.) обосновывалась самостоятельность отрасли советского финансового права в системе отраслей права, получила развитие концепция советских финансовых правоотношений, закладывались основы правовых дисциплин - сравнительного и международного фринансового права (Е.А. Ровинский, В.И. Лисовский). Наиболее видным теоретиком финансового права советского периода можно признать Е.А. Ровинского. Основное внимание уделялось вопросам правового регулиро-

Халфина Р.О. К вопросу о предмете и системе советского финансового права // Вопросы советского административного и финансового права. М., 1952. С. 195.

6 История финансового законодательства России / под ред. И.В. Рукавишниковой. М., 2003. С. 6. вания бюджетных отношений (М.И. Пискотин, В.В. Бесчеревных, а также Н.И. Химичева, Л.К. Воронова, О.Н. Горбунова и др.). Правовые проблемы налогов и денежного обращения зачастую отодвигались на второй план по политическим причинам (общая недооценка налогов и попытка их отмены, план построения коммунизма, основанного на бестоварной (а значит, и безденежной) экономике и др.). Но нельзя не упомянуть о трудах С.Д. Цыпкина, посвященных налогу как институту финансового права. В этой части можно согласиться с утверждением К.С. Бельского об одностороннем развитии советской науки финансового права, которая должна была обслуживать прежде всего интересы социалистического государства и заниматься преимущественно проблемами бюджетного права ${ }^{7}$. Несомненно, советские ученые внесли вклад в развитие финансово-правовой мысли в обозначенный период. Однако в целом он не соответствовал тому научному потенциалу, который мог бы развиться, но в силу идеологических ограничений, изоляции от зарубежных финансовоправовых исследований этого не произошло.

Российская наука фринансового права на рубеже $X X-X X I$ вв. В это время она переживала переломный период, вызванный коренными изменениями всей политической и социально-экономической системы российского общества. Советская модель финансового права уже не отвечала запросам времени, не соответствовала формирующейся финансовой системе российского государства. Для постсоветской науки актуальной и практически значимой стала разработка новой во многих отношениях, принципиально иной концепции отрасли российского финансового права.

Но любые новеллы в правовом механизме регулирования финансовых отношений не исключают, а скорее предполагают преемственность в развитии науки фринансового права. Нам уже известен печальный советский опыт отрицания преемственности в отношении «буржуазных теорий финансового права», обоснования юридических конструкций «с чистого листа», опираясь на единственно верное учение марксизма-ленинизма и исключительно собственный опыт построения социалистического государства. Преемственность в юридической науке в целом и финансовом праве в частности служит необходимым элементом ее поступательного развития. В этой связи вполне понятен и обоснован повышенный интерес современных исследователей к историческим

Бельский К.С. Финансовое право. М., 1995. С. 67. 
истокам, анализу финансово-правовых исследований ученых, государственных деятелей России XVIII-XX вв. (К.С. Бельский, А.А. Ялбулганов и др. $)^{8}$. В досоветский период на базе императорских университетов сформировалась российская школа фринансового права. Российские ученые-финансисты нередко совмещали в той или иной степени научную и служебную деятельность. По уровню проводимых фринансово-правовых исследований российская научная школа не уступала европейской. Это были исследования, основанные на историческом и сравнительно-правовом методах, единстве экономического и правового анализа фринансовых явлений.

Научное осмысление феномена советского финансового права также не менее значимо для современных исследователей. Несмотря на жесткие идеологические рамки, изоляцию от мировой науки, тем не менее советскими учеными были заложены теоретические основы для дальнейшего развития науки финансового права. Именно с советским периодом связывается ее окончательное обособление и самостоятельное место в системе юридических наук. Таким образом, изучение разработанных в досоветский и советский периоды финансово-правовых учений (о государственном (публичном) хозяйстве, впоследствии - финансовой деятельности государства; о финансовой политике государства; о бюджетном праве и бюджетном федерализме, о налоговом праве, элементах налога; праве налогоплательщиков на жалобу; о фринансовом контроле; о фринансовой администрации; о финансовых правоотношениях и др.) во многом стимулируют новые подходы к анализу современных проблем фринансового права. В переходный период от советской системы финансового права к современной обеспечивалась преемственность научных исследований благодаря трудам ранее названных ученых советской школы финансового права Н.И. Химичевой ${ }^{9}$, О.Н. Горбуновой $^{10}$, С.В. Запольского ${ }^{11}$ и др.

Бельский К.С. Финансовое право. Наука, история, библиография. М., 1995; Ялбулганов А.А. Очерки истории финансового права дореволюционной России. М., 1998 и др.

Химичева Н.И. Налоговое право Российской Федерации. Саратов, 1993; Финансовое право / под ред. Н.И. Химичевой. М., 1995 и др.

10 Горбунова О.Н. Финансовое право и финансовый мониторинг в современной России. М., 2003; Финансовое право / под ред. О.Н. Горбуновой. М., 1996 и др.

11 Запольский С.В. Дискуссионные вопросы теории финансового права. М., 2008; Он же. Теория финансового права. М., 2010 и др.
Поступательное развитие современной науки финансового права связано со следующими основными направлениями научных изысканий.

В настоящее время наблюдается очевидный «разрыв» связей между отраслевой теорией и правотворчеством. Финансовое законодательство «множится и развивается вширь и глубь», кодифицируется по частям, В то время как российская наука финансового права оказывается на шаг позади нашего законодателя. При этом многие научные исследования носили и носят «реактивный характер», но не в силу своей оперативности. Скорее потому, что они являются только реакцией на изменения финансового законодательства. Между тем комментарии законодательства и практики его применения, важность которых очевидна, не могут заменить научные исследования. Кстати, и комментарии по финансовому законодательству устаревают до того, как высохнет на них типографская краска. Довольно существенный разрыв, наметившийся между законотворческой деятельностью и научной экспертизой, наносит вред не только качеству нормативных правовых актов, но и развитию науки.

На этот вызов российская наука финансового права отвечает фундаментальными исследованиями проблем, прежде всего общей части фринансового права. Каждая из этих проблем сегодня остается дискуссионной, начиная с системообразующих категорий фринансового права. Это касается и финансов, и финансовой системы, и финансовой деятельности государства (С.В. Запольский, Э.Д. Соколова и др. $)^{12}$.

Принципиальный вопрос о предмете отрасли разделил ученых на сторонников «узкой» традиционной концепции предмета отрасли, основанной на теории публичных финансов (публичных фондов, финансовой деятельности государства) и сторонников «широкой» концепции, основанной на публичном интересе, охватывающем и частные финансы. Последняя, на наш взгляд, ведет к «размыванию» предмета отрасли финансового права, его последующей дефрагментации на отдельные комплексные отрасли законодательства (подчеркнем: не отрасли права, а отрасли законодательства). В этом случае

\footnotetext{
12 Соколова Э.Д. Правовые основы финансовой системы России. М., 2006; Она же. Правовое регулирование финансовой деятельности государства и муниципальных образований. М., 2009 и др.
} 
оно разделяется на страховое законодательство, инвестиционное законодательство, банковское законодательство и т.д. Деление права по отраслям законодательства характерно для англо-саксонской системы права. Российская правовая система тяготеет все же к континентальной правовой системе. Это обстоятельство современные исследователи должны учитывать.

Более того, напомним о преемственности в развитии российского финансового права и науки финансового права. В основе же названной дискуссии о предмете современного финансового права в конечном счете лежит вопрос о единстве публичных и частных начал в правовом регулировании финансовых отношений. Данный вопрос предопределяет и новые подходы к характеристике метода отрасли. Сегодня метод не ограничивается императивными элементами, а включает координационные способы правового регулирования, способы согласования, правовых рекомендаций, поощрений, договорно-правового регулирования (М.В. Карасева, И.В. Рукавишникова $\left.{ }^{13}\right)$. Применительно к концепции финансовых правоотношений этот вопрос предполагает обращение к их имущественной доминанте (М.В. Карасева ${ }^{14}$ ). Не менее актуальными и спорными остаются проблемы системы, структуры отрасли российского финансового права, финансово-правовой ответственности как самостоятельного вида юридической ответственности; отраслевых принципов и источников фринансового права.

Сегодня идет неустанный поиск новой парадигмы российского фринансового права. Наряду с традиционными отраслевыми подходами, основанными на единстве отрасли, заявляются новаторские подходы. Одни ученые связывают будущее российского финансового права с его фрормированием как федерального коллизионного права (Д.В. Винницкий $\left.{ }^{15}\right)$, другие - с ролью макроотрасли (С.В. Запольский). Но в любом случае такие подходы, рано или поздно, «раскрутят маховик центробежной силы», разделяющей финансовое право на самостоятельные отрасли права. Во благо такой процесс для российской правовой системы или нет - покажет время.

\footnotetext{
13 Рукавишникова И.В. Метод финансового права. М., 2004 и др.

14 Карасева М.В. Финансовое правоотношение. М., 2001 и др.

15 Актуальные проблемы финансового права Республики Беларусь, России, Украины. М., 2006. С. 28-29.
}

Активное обновление правовой основы финансовых отношений послужило «катализатором» для расширения сферы научных изысканий, особенно в тех областях, которые ранее оставались «в тени». В первую очередь это касалось проблем налогового права (А.В. Брызгалин ${ }^{16}$, Д.В. Винницкий ${ }^{17}$, С.Г. Пепеляев ${ }^{18}$, Г.В. Петрова ${ }^{19}$; А.В. Демин ${ }^{20}$, и др.) и валютного права (Б.Ю. Дорофеев, Н.Н. Косаренко, А.А. Тедеев ${ }^{21}$ и др.) в структуре фринансового права. Сохранили свою злободневность и вопросы бюджетного права, бюджетного федерализма (Ю.А. Крохина ${ }^{22}$, Н.А. Шевелева ${ }^{23}$ и др.), фринансового контроля (Е.Ю. Грачева и др.) $)^{24}$. Изменились и наполнились новым содержанием традиционные институты и подотрасли финансового права. В налоговом праве особую актуальность приобрели проблемы правовых пределов налоговой оптимизации, прав налогоплательщика на налоговую оптимизацию (С.В. Савсерис, Д.М. Щекин и др. ${ }^{25}$ ). Получили обоснование новые институты: учетного права, объединяющего правовое регулирование налогового, бюджетного и бухгалтерского учета (Е.М. Ашмарина $\left.{ }^{26}\right)$, новые подотрасли

16 Налоги и налоговое право / под ред. А.В. Брызгалина. М., 1997; Налоги, люди, время... / под ред. А.В. Брызгалина. Екатеринбург, 2008 и др.

17 Винницкий Д.В. Российское налоговое право. СПб., 2003 и др.

18 Основы налогового права / под ред. С.Г. Пепеляева. М., 1996; Налоговое право / отв. ред. С.Г. Пепеляев. М., 2003 и др.

19 Петрова Г.В. Общая теория налогового права. М., 2004 и др.

20 Демин А.В. Нормы налогового права. Красноярск, 2010 и др.

${ }^{21}$ Дорофеев Б.Ю., Земцов Н.Н., Пушин В.А. Валютное право России. М., 2000; Косаренко Н.Н. Валютное право. М., 2010; Тедеев А.А. Валютное право. СПб., 2009 и др.

22 Крохина Ю.А. Бюджетное право и российский федерализм. М., 2002 и др.

23 Шевелева Н.А. Бюджетная система России. СПб., 2004 и др.

24 Грачева Е.Ю. Проблемы правового регулирования государственного финансового контроля. М., 2000; Грачева Е.Ю., Толстопятенко Г.П., Рыжкова Е.А. Финансовый контроль. М., 2004 и др.

25 Щекин Д.М. Налоговые риски и тенденции развития налогового права. М., 2007; Савсерис С.В. Категория «недобросовестность» в налоговом праве. М., 2007 и др.

26 Ашмарина Е.M. Некоторые аспекты расширения предмета финансового права в Российской Федерации: проблемы и перспективы. М., 2004; Правовые основы бухгалтерского учета и аудита в Российской Федерации / под ред. Е.М. Ашмариной. М., 2011 и др. 
фринансового права. В последнем случае речь идет о подотраслях: право денежного обращения, включающее наличные и безналичные формы денежного обращения в национальной и иностранной валюте (Н.М. Артемов $^{27}$, Л.Л. Арзуманова $\left.{ }^{28}\right)$, государственный и муниципальный кредит (Е.В. Покачалова ${ }^{29}$ ), право рынка ценных бумаг, инвестиционное право и др. (Г.В. Петрова $\left.{ }^{30}\right)$. В современной науке можно встретить предложения о принятии Денежно-кредитного кодекса ${ }^{31}$.

В целях возможной рецепции зарубежного опыта ученые обратились и к сравнительно-правовым исследованиям финансового законодательства зарубежных стран (А.Н. Козырин, И.И. Кучеров и др. $\left.{ }^{32}\right)$. Актуализировались проблемы гармонизации и унификации европейского налогового права (Г.П. Толстопятенко ${ }^{33}$ и др.), налогового законодательства стран СНГ и ЕврАзЭС (Д.В. Винницкий, Д.М. Щекин и др. ${ }^{34}$ ). Идет возрождение прежних дореволюционных традиций исследования любого финансовоправового явления в сравнительно-правовом ключе. Хотя канули в лету советские методы огульной критики «буржуазных финансовых теорий на службе государству», но мы еще в начале этого пути.

В современных условиях состояние и тенденции развития российской финансовой системы нельзя правильно понять и оценить без учета ее связей с международной средой.

7 Денежное право (финансово-правовое регулирование обращения национальной и иностранной валюты на территории Российской Федерации). М., 2011 и др.

28 Арзуманова Л.Л. Денежное обращение и история его развития. Финансово-правовой аспект. М., 2013.

29 Покачалова Е.В. Становление и развитие публичного долга и его форм (Финансово-правовые аспекты). Саратов, 2007.

30 Петрова Г.В. Финансовое право. М., 2006 и др.

31 Рыбакова С.В. Финансирование и банковское право (теоретические аспекты соотношения). Саратов, 2009 и др.

32 Козырин А.Н. Налоговое право зарубежных стран: вопросы теории и практики. М., 1993; Он же. Финансовое право и управление финансами в зарубежных странах. М., 2009; Кучеров И.И. Налоговое право зарубежных стран. М., 2003; Отдельные финансово-правовые институты зарубежных стран / под ред. В.А. Белова. М., 2009 и др.

33 Толстопятенко Г.П. Европейское налоговое право. М., 2001 и др.

34 Налоговое право Евразийского экономического сообщества / под ред. Д.В. Винницкого, М., 2010; Щекин Д.М. Налоговое право государств-участников СНГ (Общая часть). М., 2008 и др.
В этой связи особое внимание исследователями уделяется международному финансовому праву, обосновывается самостоятельность этой отрасли в международно-правовой системе, выделяются институты общей и особенной частей отрасли (В.М. Шумилов, И.И. Кучеров, Г.В. Петрова ${ }^{35}$ и др.).

Эффрективность исследований проблем фринансового права напрямую связана с их организационной основой - развитием школ фринансового права на базе специализированных кафедр высших учебных заведений. В дореволюционной России кафредры фринансового права были в университетах Москвы (московская школа), Казани (казанская школа), Одессы (новороссийская школа) и др., в советской России - не было ни одной. Финансовое право, как правило, «квартировалось» на кафедрах административного или гражданского права ${ }^{36}$. Ныне обособление кафедр финансового права стало реальностью, и этот процесс еще не завершен.

Сегодня отечественная наука фринансового права не ограничивается только московской и петербургской школами. Продолжили свои традиции сложившиеся еще в советский период саратовская школа финансового права (Н.И. Химичева, Е.В. Покачалова, О.Ю. Бакаева, Е.Н. Пастушенко и др. $\left.{ }^{37}\right)$. Заявили о себе екатеринбургская школы (Д.В. Винницкий, А.В. Брызгалин и др.) и воронежская школы финансового права (М.В. Карасева и др. $\left.{ }^{38}\right)$. Развитие единой российской школы финансового права и составляющих ее региональных школ продолжается.

35 Кучеров И.И. Международное налоговое право. М., 2007; Петрова Г.В. Международное финансовое право. М., 2009; Шумилов В.М. Международное финансовое право. М., 2005 и др.

36 Бельский К.С. Финансовое право. М., 1995. С. 71.

37 Финансовое право / отв. ред. Н.И. Химичева. М., 2011; Пастушенко Е.Н. Правовые акты Центрального банка Российской Федерации. Саратов, 2006; Бакаева О.Ю. Таможенные фискальные доходы: правовое регулирование. М., 2005; Покачалова Е.В. Публичный долг в Российской Федерации: вопросы теории финансового права. Саратов, 2007 и др.

38 Бюджетное и налоговое правовое регулирование: единство и дифференциация / под ред. М.В. Карасевой. М., 2012; Карасева М.В. Бюджетное и налоговое право России. Политический аспект. М., 2003; Пауль А.Г. Бюджетно-правовое регулирование формирования доходов бюджетов. Воронеж, 2011 и др. 


\section{Библиография:}

1. Актуальные проблемы финансового права Республики Беларусь, России, Украины. - М., 2006.

2. Арзуманова Л.Л. Денежное обращение и история его развития. Финансово-правовой аспект. - М., 2013.

3. Ашмарина Е.М. Некоторые аспекты расширения предмета фринансового права в Российской Федерации: проблемы и перспективы. - М., 2004.

4. Бакаева О.Ю. Таможенные фискальные доходы: правовое регулирование. - М., 2005.

5. Бельский К.С. Финансовое право. Наука, история, библиография. - М., 1995.

6. Винницкий Д.В. Российское налоговое право. - СПб., 2003.

7. Горбунова О.Н. Финансовое право и финансовый мониторинг в современной России. - М., 2003.

8. Грачева Е.Ю. Проблемы правового регулирования государственного финансового контроля. - М., 2000.

9. Демин А.В. Нормы налогового права. - Красноярск, 2010.

10. Денежное право (финансово-правовое регулирование обращения национальной и иностранной валюты на территории Российской Федерации). - М., 2011.

11. Дорофеев Б.Ю., Земцов Н.Н., Пушин В.А. Валютное право России. - М., 2000.

12. Запольский С.В. Дискуссионные вопросы теории финансового права. - М., 2008.

13. Запольский С.В. Теория финансового права: научные очерки. - М., 2010.

14. История финансового законодательства России / под ред. И.В. Рукавишниковой. - М., 2003.

15. Карасева М.В. Финансовое правоотношение. - М., 2001.

16. Козырин А.Н. Налоговое право зарубежных стран: вопросы теории и практики. - М., 1993.

17. Косаренко Н.Н. Валютное право. - М., 2010.

18. Крохина Ю.А. Бюджетное право и российский федерализм. - М., 2002.

19. Кучеров И.И. Налоговое право зарубежных стран. - М., 2003.

20. Лушникова М.В., Лушников А.М. Наука финансового права на службе государству: российские государственные деятели и развитие науки финансового права. - Ярославль, 2010.

21. Лушникова М.В., Лушников А.М. Развитие науки финансового права в России. - СПб., 2013.

22. Лушникова М.В., Лушников А.М. Российская школа финансового права: портреты на фоне времени. - Ярославль, 2013.

23. Налоги и налоговое право / под ред. А.В. Брызгалина. - М., 1997.

24. Налоговое право / отв. ред. С.Г. Пепеляев. - М., 2003.

25. Налоговое право Евразийского экономического сообщества / под ред. Д.В. Винницкого. M., 2010.

26. Основы налогового права / под ред. С.Г. Пепеляева. - М., 1996.

27. Пастушенко Е.Н. Правовые акты Центрального банка Российской Федерации. - Саратов, 2006.

28. Петрова Г.В. Международное финансовое право. - М., 2009.

29. Петрова Г.В. Общая теория налогового права. - М., 2004.

30. Покачалова Е.В. Становление и развитие публичного долга и его форм (финансово-правовые аспекты). - Саратов, 2007.

31. Рукавишникова И.В. Метод финансового права. - М., 2004.

32. Савсерис С.В. Категория «недобросовестность» в налоговом праве. - М., 2007.

33. Соколова Э.Д. Правовое регулирование финансовой деятельности государства и муниципальных образований. - М., 2009.

34. Соколова Э.Д. Правовые основы финансовой системы России. - М., 2006.

35. Толстопятенко Г.П. Европейское налоговое право. - М., 2001.

36. Химичева Н.И. Налоговое право Российской Федерации. - Саратов, 1993.

37. Шевелева Н.А. Бюджетная система России. - СПб., 2004.

38. Щекин Д.М. Налоговое право государств-участников СНГ (Общая часть). - М., 2008.

39. Щекин Д.М. Налоговые риски и тенденции развития налогового права. - М., 2007.

40. Ялбулганов А.А. Очерки истории фринансового права дореволюционной России. - М., 1998. 


\section{References (transliteration):}

1. Lushnikova M.V., Lushnikov A.M. Razvitie nauki finansovogo prava v Rossii. - Spb., 2013.

2. Zapol'skii S.V. Teoriya finansovogo prava: Nauchnye ocherki. - M., 2010.

3. Lushnikova M.V., Lushnikov A.M. Rossiiskaya shkola finansovogo prava: portrety na fone vremeni. - Yaroslavl', 2013.

4. Lushnikova M.V., Lushnikov A.M. Nauka finansovogo prava na sluzhbe gosudarstvu: rossiiskie gosudarstvennye deyateli i razvitie nauki finansovogo prava. - Yaroslavl', 2010.

5. Istoriya finansovogo zakonodatel'stva Rossii / Pod red. I.V. Rukavishnikovoi. - M., 2003.

6. Bel'skii K.S. Finansovoe pravo. Nauka, istoriya, bibliografiya. - M., 1995.

7. Yalbulganov A.A. Ocherki istorii finansovogo prava dorevolyutsionnoi Rossii. - M., 1998.

8. Khimicheva N.I. Nalogovoe pravo Rossiiskoi Federatsii. - Saratov, 1993

9. Gorbunova O.N. Finansovoe pravo i finansovyi monitoring v sovremennoi Rossii. - M., 2003

10. Zapol'skii S.V. Diskussionnye voprosy teorii finansovogo prava. - M., 2008.

11. Sokolova E.D. Pravovye osnovy finansovoi sistemy Rossii. - M., 2006.

12. Sokolova E.D. Pravovoe regulirovanie finansovoi deyatel'nosti gosudarstva i munitsipal'nykh obrazovanii. - M., 2009.

13. Rukavishnikova I.V. Metod finansovogo prava. - M., 2004.

14. Karaseva M.V. Finansovoe pravootnoshenie. - M., 2001.

15. Aktual'nye problemy finansovogo prava Respubliki Belarus', Rossii, Ukrainy / Gracheva E.Yu., Vinnitskii D.V. i dr. - M., 2006.

16. Nalogi i nalogovoe pravo / pod red. A.V. Bryzgalina. - M., 1997.

17. Vinnitskii D.V. Rossiiskoe nalogovoe pravo. - SPb., 2003.

18. Osnovy nalogovogo prava / pod red. S.G.Pepelyaeva. - M., 1996.

19. Nalogovoe pravo / otv. red. S.G.Pepelyaev. - M., 2003.

20. Petrova G.V. Obshchaya teoriya nalogovogo prava. - M., 2004.

21. Demin A.V. Normy nalogovogo prava. - Krasnoyarsk, 2010.

22. Dorofeev B.Yu., Zemtsov N.N., Pushin V.A. Valyutnoe pravo Rossii. - M., 2000.

23. Kosarenko N.N. Valyutnoe pravo. - M., 2010.

24. Krokhina Yu.A. Byudzhetnoe pravo i rossiiskii federalizm. - M., 2002.

25. Sheveleva N.A. Byudzhetnaya sistema Rossii. - SPb., 2004.

26. Gracheva E.Yu. Problemy pravovogo regulirovaniya gosudarstvennogo finansovogo kontrolya. M., 2000.

27. Shchekin D.M. Nalogovye riski i tendentsii razvitiya nalogovogo prava. - M., 2007.

28. Savseris S.V. Kategoriya «nedobrosovestnost'» v nalogovom prave. - M., 2007.

29. Ashmarina E.M. Nekotorye aspekty rasshireniya predmeta finansovogo prava $v$ Rossiiskoi Federatsii: problemy i perspektivy. - M., 2004.

30. Denezhnoe pravo (finansovo-pravovoe regulirovanie obrashcheniya natsional'noi i inostrannoi valyuty na territorii Rossiiskoi Federatsii) / N.M. Artemov, L.L. Arzumanova i dr. - M., 2011.

31. Arzumanova L.L. Denezhnoe obrashchenie i istoriya ego razvitiya. Finansovo-pravovoi aspekt. M., 2013.

32. Pokachalova E.V. Stanovlenie i razvitie publichnogo dolga i ego form (Finansovo-pravovye aspekty). - Saratov, 2007.

33. Kozyrin A.N. Nalogovoe pravo zarubezhnykh stran: voprosy teorii i praktiki. - M., 1993.

34. Kucherov I.I. Nalogovoe pravo zarubezhnykh stran. - M., 2003.

35. Tolstopyatenko G.P. Evropeiskoe nalogovoe pravo. - M., 2001.

36. Nalogovoe pravo Evraziiskogo ekonomicheskogo soobshchestva / pod. red. D.V. Vinnitskogo. M., 2010.

37. Shchekin D.M. Nalogovoe pravo gosudarstv-uchastnikov SNG (Obshchaya chast'). - M., 2008.

38. Petrova G.V. Mezhdunarodnoe finansovoe pravo. - M., 2009.

39. Pastushenko E.N. Pravovye akty Tsentral'nogo Banka Rossiiskoi Federatsii. - Saratov, 2006.

40. Bakaeva O.Yu. Tamozhennye fiskal'nye dokhody: pravovoe regulirovanie. - M., 2005. 